\title{
Persepsi Mahasiswa Tentang Penerapan Kawasan Tanpa Rokok (KTR) Di Universitas Aufa Royhan Padangsidimpuan Tahun 2019
}

\author{
Aprilda Yanti ${ }^{1}$, Arinil Hidayah², Yanna Wari Harahap ${ }^{3}$ \\ ${ }^{1}$ Mahasiswa Program Studi Ilmu Kesehatan Masyarakat Program Sarjana Universitas Aufa \\ Royhan, ${ }^{2}$ Dosen Program Studi Ilmu Kesehatan Masyarakat Program Sarjana Universitas Aufa \\ Royhan, \\ Email : aprildayantisrg@gmail.com¹
}

\begin{abstract}
Abstrak
Pemerintah Daerah kota padangsidimpuan mengeluarkan peraturan daerah Nomor 07 Tahun 2012 Tentang Kawasan Tanpa Rokok. Universitas Aufa Royhan merupakan salah satu instansi pendidikan yan berada di kota padangsidimpuan. Permasalahan penelitian adalah bagaimana persepsi mahasiswa universitas aufa royhan dalam menanggapi penerapan peraturan KTR di universitas aufa royhan dan gambaran pemahaman mahasiswa tentang KTR. Jenis penelitian ini adalah deskriptif dengan metode kualitatif melalui wawancara mendalam. (indepth interwiew). Instrumen dalam penelitian ini adalah peneliti sendiri, alat pengumpulan data lainnya dalam penelitian ini adalah perekam suara, dan catatan lapangan. Informan dalam penelitian ini sebanyak 6 mahasiswa yang setuju untuk diwawancarai serta menanda tangani lembar persetujuan menjadi informan.berdasarkan hasil wawancara yang telah dilakukan, keenam informan memiliki pemaham yang baik tentang kawasan tanpa rokok. Sebanyak 4 informan memberikan pandangan positif terhadap penerapan KTR di universitas Aufa Royhan dengan alasan untuk menghindari bahaya paparan asap rokok bagi perokok pasif dan status Universitas Aufa Royhan sebagai kampus kesehatan. Kemudian, 2 informan lainnya menolak penerapan KTR di universitas aufa royhan.
\end{abstract}

\section{Kata Kunci : Kawasan tanpa rokok, persepsi, penelitian kualitatif}

\section{Abstract}

The Regional Government of the city of Padangsidimpuan issued local regulation No. 07 of 2012 concerning No-Smoking Areas.Aufa Royhan University is one of the educational institutions in the city of Padangsidimpuan. The research problem is how the perception of aufa royhan university students in responding to the application of No Smoking Area regulations at aufa royhan university and a description of students understanding of No Smoking Area. This type of research is descriptive with qualitative methods through in-depth interviews. (indepth interwiew). The instruments in this study were the researchers themselves, other data collection tools in this study were voice recorders, and field notes. Informants in this study were 6 students who agreed to be interviewed and signed the consent form to be the informant. Based on the results of interviews conducted, the six informants have a good understanding of the non-smoking area. Four informants gave positive views on the application of No Smoking Area regulations at Aufa Royhan University with the reason to avoid the danger of exposure to cigarette smoke for passive smokers and the status of Aufa 
Royhan University as a health campus. Then, 2 other informants rejected the application of KTR implementation at Aufa Royhan University.

Keywords : No smoking area, perception, qualitative research

\section{Pendahuluan}

Saat ini rokok menjadi salah satu produk yang tingkat konsumsinya relatif tinggi di masyarakat. Masalah rokok juga masih menjadi masalah nasional dan diprioritaskan upaya penanggulangannya karena menyangkut berbagai aspek permasalahan dalam kehidupan, yaitu aspek ekonomi, sosial politik dan terutama aspek kesehatan (Kemenkes RI, 2011).

Berdasarkan data organisasi kesehatan dunia (WHO) Global Tobacco Control Report (GTCR) 2015 Yang dikutip dari Depkes RI, Indonesia menempati urutan ketiga konsumsi rokok terbesar di dunia setelah China dan India. Sedangkan untuk Asia, Menurut Widowati (2019) yang mengutip data dari Southeast Asia Tobacco Control Alliance (SEATCA) atau aliansi pengendalian tembakau di Asia bekerja sama dengan IAKMI (IAKMI-SEATCA), menyatakan Indonesia merupkan negara dengan jumlah perokok tebesar nomor satu di Asean, yakni 65,19 juta orang. Angka tersebut setara 34\% dari total penduduk Indonesia pada tahun 2016.

Peningkatan konsumsi rokok berdampak pada makin tingginya beban penyakit akibat rokok dan bertambahnya angka kematian akibat rokok. Tahun 2030 diperkirakan angka kematian perokok di dunia akan mencapai 10 juta jiwa, dan $70 \%$ diantaranya berasal dari negara berkembang. Saat ini 50\% kematian akibat rokok berada di negara berkembang (Pedoman KTR, 2011).

Dalam upaya mengendalikan hal tersebut, pemerintah mengeluarkan peraturan yang tertuang dalam Peraturan Pemerintah (PP) No.19 Tahun 2003 tentang Pengamanan Rokok Bagi Kesehatan. Pada pasal 22 menyatakan bahwa tempat umum, sarana kesehatan, tempat kerja, tempat proses belajar mengajar, arena kegiatan anak, tempat ibadah dan angkutan umum dinyatakan sebagai kawasan tanpa rokok (KTR). PP tersebut telah diperbaharui dengan telah ditetapkannya PP No.109 Tahun 2012 tentang Pengamanan Bahan yang Mengandung Zat Adiktif Berupa Tembakau Bagi Kesehatan. Pada pasal 49 menyatakan dengan tegas bahwa Pemerintah dan Pemerintah Daerah wajib mewujudkan KTR.

Universitas Aufa Royhan, merupakan salah satu instansi pendidikan swasta yang berada di Kota Padangsidimpuan, Provinsi Sumatera Utara. dalam Undang-Undang Kesehatan No.36 Tahun 2009 Pasal 115 menyatakan bahwa instansi pendidikan merupakan tempat yang dinyatakan sebagai kawasan tanpa rokok. Hal ini juga diperkuat dengan adanya Peraturan Daerah (Perda) Kota Padangsidimpuan No.07 Tahun 2012 yang mewajibkan instansi pendidikan menerapkan KTR. Saat ini, Universitas Aufa Royhan telah menerapkan kawasan tanpa rokok di lingkungan kampus.

\section{Metode penelitian}

Penelitian ini menggunakan pendekatan kualitatif yang didefenisikan sebagai prosedur penelitian yang menghasilkan data deskrtiptif berupa hasil wawancara baik itu berupa katakaata tertulis atau lisan dari orang-orang yang ditentukan sebagai informan (Patilima dalam Lubis, 2017). 
Desain dalam penelitian ini bersfiat terbuka, disesuaikan dengan kondisi yang dijumpai di lapangan. Peneliti terjun langsung ke lapangan dan berinteraksi langsung dengan informan sampai mendapatkan informasi yang diinginkan dan lengkap.dilaksanakan sejak bulan Desember 2018 sampai dengan bulan Agustus tahun 2019. Populasi pada penelitian ini adalah seluruh mahasiswa Universitas Aufa Royhan Padangsidimpuan, dengan jumlah sampel sebanyak 6 mahasiswa yang bersedia untuk diwawancarai serta menandatangani persetujuan menjadi Informan penelitian dan terdiri dari berbagai program studi yang ada di Universitas Aufa Royhan Padangsidimpuan.

\section{Hasil penelitian}

Tabel 1. Matriks Tema

Tema 1 : Pemahaman Mahasiswa Universitas Aufa Royhan Tentang Kawasan Tanpa Rokok

Sub Tema :

1. Definisi KTR

Tema 2 : Informasi Penerapan Kawasan Tanpa Rokok di UniversitasAufa Royhan

\section{Sub Tema :}

1. Pembenaran keberadaan peraturan KTR di Aufa Royhan

2. KTR sudah berjalan di Aufa Royhan

3. Mahasiswa tidak mengetahui sejak kapan peraturan KTR berlaku

4. Tidak ada sosialisasi terkait penerapan peraturan KTR

\section{Tema 3 : Penyebab Peraturan Kawasan Tanpa Rokok Tidak Berjalan Dengan Baik Di} Universitas Aufa Royhan

\section{Sub tema :}

1. Dosen yang tidak tegas

2. Lemahnya peraturan yang diterapkan

Tema 4 : Pandangan Mahasiswa Tentang Pentingnya PenerapanKTR di Universitas Aufa RoyShan

\section{Sub Tema}

1. Pandangan Mahasiswa tentang penerapan KTR di universitas Aufa Royhan

Tema 5 : Masukan atau Saran dari Mahasiswa Untuk PenerapanKTR di Universitas Aufa Royhan

\section{Sub Tema}

1. Adakan sosialisasi tentang penerapan KTR di Universitas Aufa Royhan

2. Sediakan Ruang khusus bagi perokok aktif

3. Berikan sanksi bagi mahasiswa yang melanggar peraturan 


\section{Pembahasan \\ Persepsi Mahasiswa Tentang Penerapan Kawasan Tanpa Rokok (KTR) Di Universitas Aufa Royhan Padangsidimpuan}

hasil penelitian ditemukan 5 tema mengenai persepsi mahasiswa tentang penerapn KTR di universitas aufa royhan, yaitu :1) Kawasan tanpa rokok (KTR) adalah ruangan atau area yang dinyatakan dilarang merokok seperti pada Fasilitas pelayanan kesehatan, tempat proses belajar mengajar, arena bermain anak, tempat ibadah, angkutan umum, tempat kerja, dan setmua tempat umum baik yang terbuka maupun yang tertutup.hal ini sesuai dengan definisi KTR menurut Perda Kota Padangsidimpuan Nomor 07 Tahun 2012 tentang definisi KTR.

"Kawasan tanpa rokok itu ialah tempat yang dilarang merokok. Misalnya seperti di tempat-tempat umum, terus di puskesmas, di rumah sakit, di sekolah,dan tempattempat umum lainnya."

2) Universitas Aufa Royhan Padangsidimpuan memiliki peraturan KTR hal ini dibuktikan lewat adanya pamplet yang ditempel dibeberapa tempat di kampus Aufa Royhan.

"Sudah ada. Tapi, hanya sebatas pampletnya saja yang berada di tempat-tempat tertentu di Aufa Royhan, seperti di kantin dan di lantai 3 dekat ruangan kesmas".

Meski sudah memiliki peraturan KTR, mahasiswa tidak mengetahui sejak kapan Aufa Royhan menerapakan peraturan tersebut dikarenakan tidak adanya sosialisasi dari pihak internal kampus.

“ kalau Sejak kapannya, pastinya saya kurang tahu. Cuma, saya tahu karena ada pamplet kawasan tanpa rokok yang dipajang pada semester genap ini”.

"Selama di sini, setahu saya sosialisasi itu belum ada . cuma, sekedar pamplet saja"

Hal tersebut tentunya berdampak pada keberhasilan penerapan peraturan KTR itu sendiri, karena tidak adanya sosialisasi terkait penerapan KTR, maka masih dijumpai mahasiswa yang merokok di lingkungan kampus.

"penerapannya belum terlaksana dengan baik. Hal ini dikarenakan saya masih sering melihat teman-teman merokok di lingkunan kampus. Pada saat pergantian jam mata kuliah menunggu dosen berikutnya masuk. pasti ada saja kak teman yang merokok tiu di pojok atau pun di ruangan"

3) Penyebab peraturan KTR tidak berjalan dengan baik di Universitas Aufa Royhan Padangsidimpuan dikarenakan pihak internal yang tidak tegas dalam menindak lanjuti mahasiswa yang ketahuan merokok di area kampus.

“...Cuma kalau ketahuan paling ditegur oleh dosen "Matikan rokokmu”. Sudah, Cuma begitu saja”

Selain itum Peraturan KTR di universitas aufa royhan masih terbilang lemah. Hal ini dikarenakan tidak adanya sanksi yang diberlakukan atas pelanggaran peraturan tersebut.

“..kalau memang serius mau untuk menerapkan KTR di kampus. seharusnya adakan sanksi..”

4)Persepsi Mahasiswa terhadap pentingnya penerapan KTR di universitas aufa royhan hasil wawancara yang telah dilakukan terhadap keenam Informan, diperoleh pandangan mahasiswa dalam menanggapi pentingnya peraturan KTR di Universitas Aufa Royhan ialah untuk 
menghindari paparan asap rokok bagi perokok pasif dan Status Aufa Royhan sebagai kampus kesehatan.

"Penting sekali. Karena rokok ini sangat berbahaya bagi mahasiswa lainnya. Apabila si perokok ini merokok di dalam ruangan yang tidak merokok pun akan terkena dampak atau akibat dari paparan asap rokok si perokok aktif tersebut"

5) Mahasiswa menyampaikan saran atau masukan dari mahasiswa untuk penerapan KTR di Aufa Royhahan :Adakan sosialisasi, Berikan sanksi bagi mahasiswa melanggar peraturan, Membangun ruang khusus merokok.

"masukan dari saya sosialisasi itu sepertinya perlu dilakukan agar semua informasi tentang kawasan tanpa rokok itu menyeluruh. Jadi, semua mahasiswa juga akan tahu kalau di Aufa Royhan itu tidak boleh merokok"

"Kalau saran dari saya... itu alangkah baiknya jika peraturan itu diperketa. Semisal kalau yang kedapatan merokok itu diberikan sanksi yang tegas biar dia ada efek jera"

"...dan juga itu hak kami sebagai seorang perokok. Kalaupun itu mau dilaksanakan di Aufa Royhan, harusnya ruang khusus untuk perokok itu harus dibuat agar hak-hak kami sebagai perokok harus dipenuhi juga.."

Berdasarkan Pembahasan diatas, diperoleh gambaranpersepsi mahasiswa tentang kawasan tanpa rokok, mahasiswa memberikan pandangan positif terhadap penerapan KTR di universitas Aufa Royhan dengan alasan untuk menghindari bahaya paparan asap rokok bagi perokok pasif dan status Universitas Aufa Royhan sebagai kampus kesehatan. Kemudian, 2 informan lainnya menolak penerapan KTR di universitas aufa royhanKTR di Universitas Aufa Royhan dengan alasan melanggar hak mereka sebagai perokok dan pembuatan kebijakan KTR atas dasar kepentingan pihak internal kampus semata dalam rangka perubahan bentuk dari STIKes menjadi Universitas.

\section{Kesimpulan dan saran}

Mahasiswa Universitas Aufa Royhan Padangsidimpuan memiliki pemahaman yang baik tentang kawasan tanpa rokok,,danPersepsi mahasiswa tentang penerapan kawasan tanpa rokok di universitas aufa royhan padangsidimpuan sudah baik.

Diharapkan penelitian ini dapat dijadikan sebagai masukan bagi pemangku kebijakan Universitas Aufa Royhan dalam upaya penerapan KTR di kampus Universitas Aufa Royhan Padangsidimpuan dan Diharapkan mahasiswa dapat mematuhi peraturan KTR yang sudah berlaku di Universitas Aufa Royhan Padangsidimpuan. 


\section{Referensi}

Aditama, T.Y. 2010. Rokok dan Kesehatan. Jakarta: Universitas Indonesia Press

Adrian. 2017. Bahaya Menjadi Perokok Pasif, Diakses dari, Pada Januari 2019.

Baharuddin.2017. "Faktor-faktor yang Berhubungan Dengan Perilaku Merokok Pada Anak Usia Remaja Madya (15-18 Tahun)".

Skripsi.Fakultas Ilmu Kesehatan. Universitaas Islam Negeri Alauddin

Depkes.2018.Hasil Riskesdas 2018. Jakarta : Departemen Kesehatan RI.

David. 2018. "Implementasi Kebijakan Kawasan Tanpa Rokok (KTR) Di Rumah Sakit Inco Soroako".

Skripsi. FISIP. Universitas Hasanuddin.

Febrian. 2014. "Persepsi Mahasiswa Terhadap Kawasan Tanpa Rokok (KTR) Dan Dukungan Penerapannya Di Sumatera Utara".

Skripsi. FKM. Universitas Sumatera Utara.

Gitrininggar. 2012. "Persepsi Mahasiswa FIB Terhadap Surat Keputusan Rektor Nomor 1805/SK/R/UI/2011 Tentang Kawasan Tanpa Rokok (KTR) Universitas Indonesia Tahun 2012”.

Skripsi. Fakultas Ilmu Keperawatan. Universitas Indonesi

Juanita. 2011. Kampus Bebas Rokok.Diakses dari http://www.kompasiana.com (pada Februari 2019)

Kemenkes RI. 2011. Pedoman Kawasan Tanpa Rokok. Kemenkes RI : Jakarta

Lubis, Nisma.2017. "Persepsi dan Pengalaman Wanita PUS tentang Alat Kontrasepsi KB Suntik 3 3bulan di Kelurahan Bincar Kecamatan Padangsidimpuan Utara”.

Skripsi.Universitas Aufa Royhan Padangsidimpuan.

Moeleong. 2015. Metodologi Penelitian Kualitatif. Bandung : Remaja Rosdakarya.

Pemerintah Indonesia. 2009. Undang-undang Republik Indonesia Nomor 36 tahun 2009 Tentang Kesehatan. Lembaran RI Tahun 2009 No. 36. Jakarta : Sekretariat Negara.

Pemerintah Kota Padangsidimpuan. 2012. Peraturan Daerah Kota Padangsidimpuan Nomor 07 Tahun 2012 Tentang Kawasan Tanpa Rokok.

Renaldi. 2013.'Implementasi Kebijakan Kawasan Tanpa Rokok (KTR) di Lingkungan Sekolah Tinggi Hang Tuah Pekan Baru”.

Jurnal. STIKes Hang Tuah Pekanbaru

Sayuti. 2017. "Implementasi Kebijakan Kawasan Tanpa Rokok (KTR) Pada Lhok Beuringen dan Puskesmas Tanah Jambo Aye di Kabupaten Aceh Utara".

Tesis. Pascasarjana Universitas Sumatera Utara.

Sobur, Alex.2016. Psikologi Umum. Bandung: Pustaka Setia. 
Widowati.2019. Indonesia, Negara Dengan Perokok Terbanyak di Asean. Diakses dari \{ https://databoks.katadata.co.id/datapublish/2019/05/31/ indonesianegara-denganperokok-terbanyak-di-asean \}, Pada Juni 2019\}

WHO - GTCR. 2015.Info Datin Tembakau. Diakses dari \{https://www.depkes.go.id/info+datin+tembakau\} pada Mei 2019 